PROFILE OF SACRAMENTO RIVER, FREEPORT TO VERONA, CALIFORNIA, FLOOD OF FEBRUARY 1986

By J.C. Blodgett and J.B. Lucas

U.S. GEOLOGICAL SURVEY

Open-File Report 88-82 


\section{DEPARTMENT OF THE INTERIOR}

DONALD PAUL HODEL, Secretary

U.S. GEOLOGICAL SURVEY

Dallas L. Peck, Director

For additional information write to:

Copies of this report may be purchased from:

U.S. Geological Survey Books and Open-File Reports Federal Center, Bldg. 810 Box 25425

Denver, CO 80225 


\section{CONTENTS}

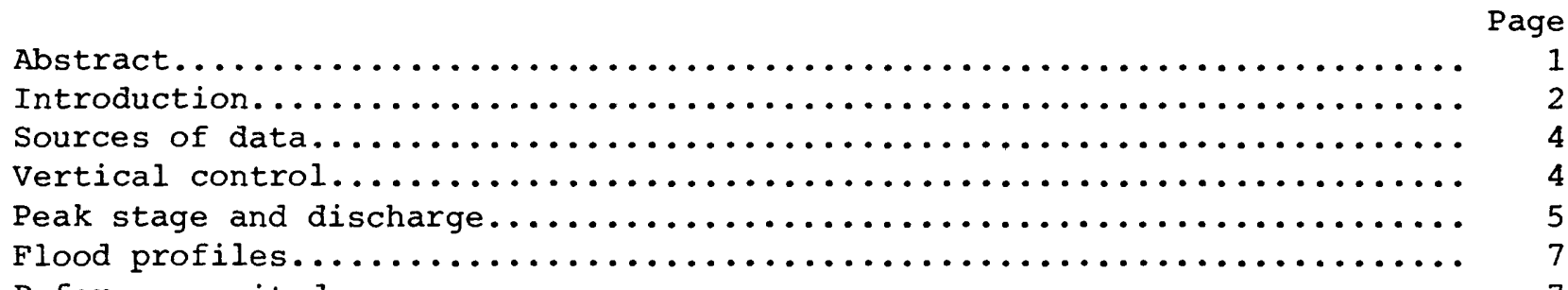

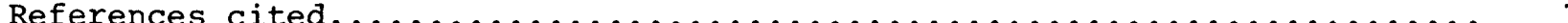

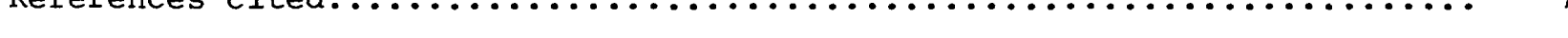

\section{ILLUSTRATIONS}

Plate 1. Map and profile of Sacramento River, Freeport to Verona, California, flood of February 19 and $20,1986 \ldots \ldots \ldots \ldots$. . . pocket

Figure 1. Map showing location of study area in vicinity of

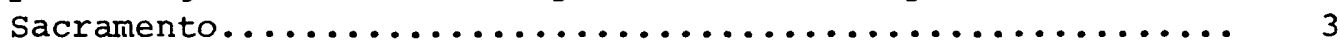

2. Photograph showing Sacramento Weir spill to Yolo Bypass near Sacramento, February 18, 1986..................... 5

3. Photograph showing Sacramento River at Sacramento gage, February 18, 1986.

\section{TABLES}

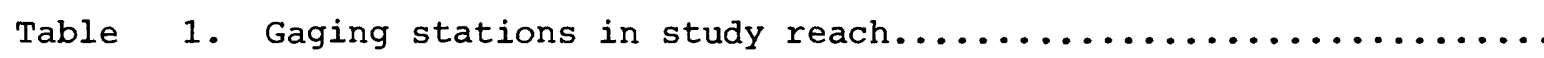

2. Annual peak stage and discharge of the Sacramento River

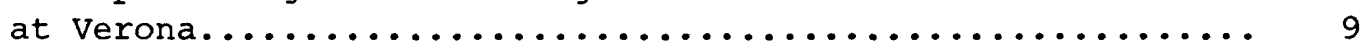

3. Annual peak stage and discharge of the American River

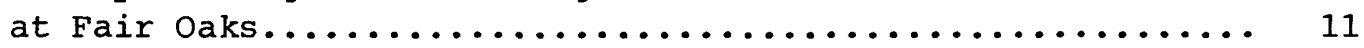

4. Selected annual peak stage and discharge of the Sacramento River at Sacramento........................... 14

5. February 1986 peak stage and discharge at selected gaging stations on the American and Sacramento Rivers............. 


\section{CONVERSION FACTORS}

For readers who prefer to use metric (International system) units rather than inch-pound units, the conversion factors for the terms used in this report are listed below:

\section{Multiply inch-pound unit}

foot ( $f t$ )

cubic foot per second $\left(\mathrm{ft}^{3} / \mathrm{s}\right)$ inch

mile (mi)
$\underline{B y}$

0.3048

0.3048

25.40

1.609
To obtain metric unit

meter

cubic meter per second millimeter

kilometer

\section{DEFINITIONS}

Sea level: In this report, sea level refers to the National Geodetic Vertical Datum of 1929 (NGVD of 1929)--A geodetic datum derived from a general adjustment of the first-order level nets of both the United States and Canada, formerly called mean sea level of 1929 .

Water year: The 12-month period ending September 30 each year is termed the "water year"; for example, the year that ended september 30, 1986, was the "1986 water year." 


\title{
PROFILE OF SACRAMENTO RIVER, FREEPORT TO VERONA, CALIFORNIA, FLOOD OF FEBRUARY 1986
}

By J.C. Blodgett and J.B. Lucas

\begin{abstract}
A major storm in February 1986 caused record flooding in the Sacramento River and other nearby basins in north-coastal and central California. As part of an effort to document this flood, the peak water-surface profile of a 33-mile reach of the Sacramento River was surveyed between Freeport and Verona, California. Supplementary profiles in this reach include elevations of the approximate top of levee, flood plain, and the water surface on March 17, 1987. On the Sacramento River at Sacramento, the peak discharge of 117,000 cubic feet per second occurred February 19 and 20, 1986. The peak stage of 30.58 feet on February 19 is the highest of record, including the period prior to construction of large flood-control dams in the Sacramento River basin beginning with Shasta Dam in 1942. The February 1986 flood profile of the Sacramento River between the mouth of the American River and the Sacramento Weir (located upstream from the American River) shows a reverse water-surface slope with a corresponding drop of about 0.13 foot. On the Sacramento River at Verona, upstream from Sacramento, a peak stage of 39.11 feet occurred February 20 (peak discharge 92,900 cubic feet per second) due to runoff from upstream tributaries. The February 1986 peak stage is the highest of record for 1914-87 (no record for years 1918-20, 1922-25). The previous peak stage of record at verona, March 1 , 1940, was 38.20 feet, with a discharge of 79,200 cubic feet per second.
\end{abstract}




\section{INTRODUCTION}

A major storm system caused widespread flooding in north-coastal and central California during February 1986. The area most affected by this storm extends from Eureka south to Santa Cruz (fig. 1). The intensity of the storm is indicated by 24-hour precipitation totals ranging from about 5 inches in the Coast Ranges to over 8 inches in the Sierra Nevada (National Oceanic and Atmospheric Administration, 1986).

Basins significantly affected by the storm include the lower Russian, Yuba, Feather, Napa, Cosumnes, Mokelumne, American, and Sacramento Rivers. Peaks-ofrecord occurred in the Napa, lower Russian, Cosumnes, American, and Sacramento Rivers. On the North Fork American River near Auburn, a coffer dam failed on February 18 at the site of the proposed Auburn Dam; the uncontrolled flow was contained in Folsom Lake a few miles downstream. The flood of February 1986 on the Sacramento River in the vicinity of Sacramento is the highest of record, including the period prior to construction of large flood-control dams in the Sacramento River basin beginning with Shasta Dam in 1942.

This report documents the February 19 and 20, 1986, peak water-surface profile of the Sacramento River, peak discharges of the Sacramento and American Rivers, and datum for five gaging stations located in a 33-mi reach between Freeport and Verona (fig. 1). Flows of the Sacramento River are measured at the downstream end (Freeport gage) and at the upstream end of the study reach (Verona gage) about $1 \mathrm{mi}$ downstream from the Fremont Weir. This weir controls the combined overflow to Yolo Bypass from the Sacramento River, Sutter Bypass, and Feather River (pl. 1). The major tributaries in the study reach are the cross canal (near Verona), Natomas east main drainage canal, and American River (pl. 1). Flows of the American River (fig. 1), a major tributary of the Sacramento River, are measured at the American River at Fair Oaks gage. Major drains that are pumped into the Sacramento or American Rivers in the study reach are the north drainage canal, Natomas main drainage canal, and several storm drains in the city of Sacramento and suburbs.

A water-surface profile of a minor flood was surveyed March 17, 1987 (discharge $37,000 \mathrm{ft}^{3} / \mathrm{s}$ ), which shows a typical profile in the reach without the effect of overflow across the Sacramento Weir to Yolo Bypass. To indicate the elevation of the levees and flood plain, approximate profiles of the top of levee and flood plain are shown on plate 1. A flood plain is a nearly flat alluvial lowland bordering a stream, formed by stream processes, that is subject to inundation by floods (Brice and Blodgett, 1978, p. 161). 


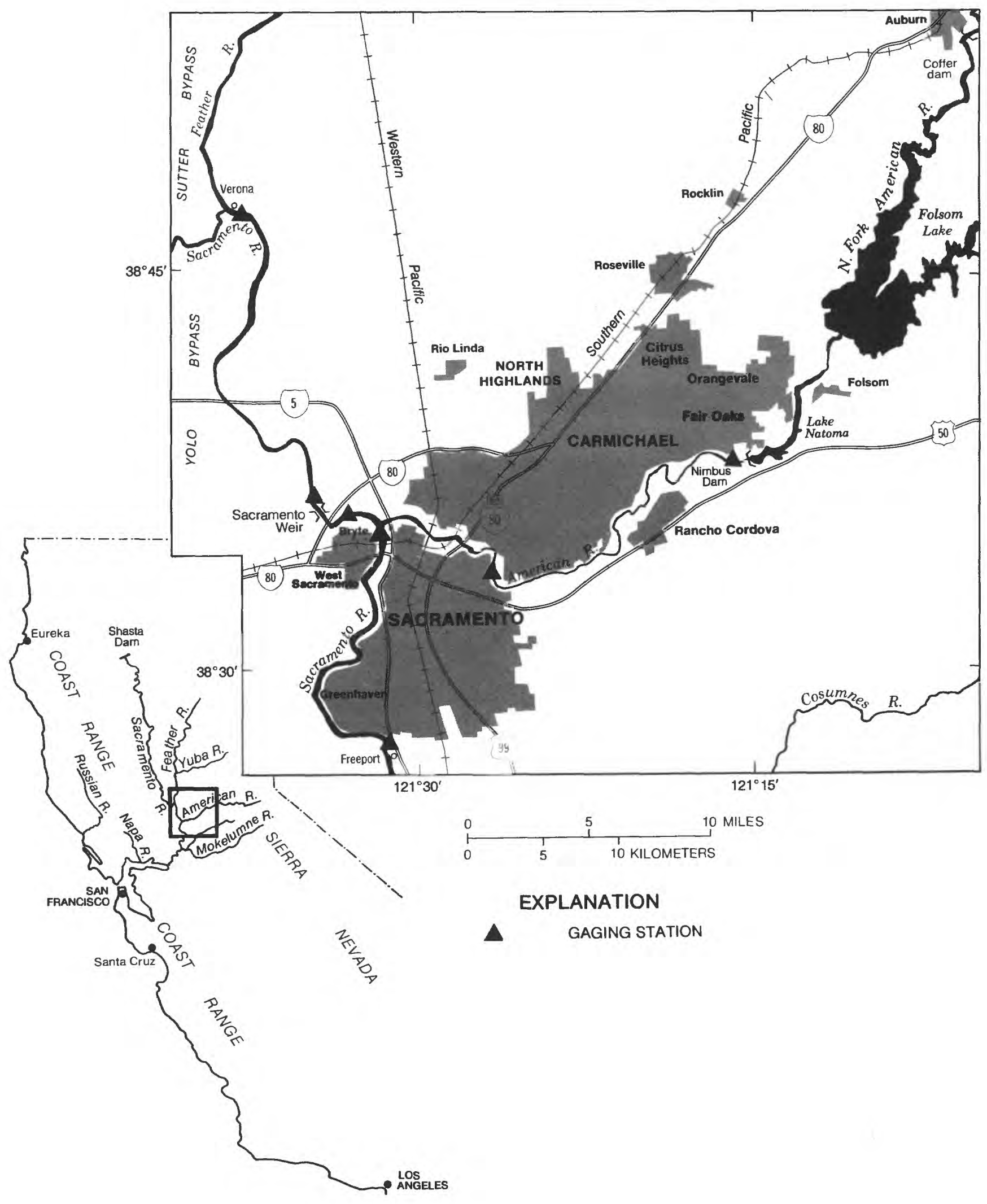

FIGURE 1. Location of study area in vicinity of Sacramento. 


\section{SOURCES OF DATA}

Flood-profile data of the Sacramento River were obtained at several gaging stations (table 1) and miscellaneous sites in the study reach. One of the gages, Sacramento River near Freeport (auxiliary water-stage recorder), has been discontinued; however, high-water marks were found in the gage structure. Floodprofile data at other sites were obtained from high-water marks and flood elevations observed by local residents. The miscellaneous sites were selected to provide elevations in sufficient detail so that local-channel effects on the water-surface profile could be determined between the various gaging stations.

Flood stage and discharge data for Geological Survey gaging stations were assembled and processed by Robert Simpson of the Sacramento field office. All photographs were furnished by Brian Yost of the Sacramento project office. Flood data for the gages American River at Sacramento; Sacramento River at Bryte Laboratory, near Bryte; Sacramento River above Sacramento Weir near Sacramento; and Sacramento Weir spill to Yolo Bypass were furnished by California Department of Water Resources (H.W. Wolber, written commun., 1987).

\section{VERTICAL CONTROL}

All vertical control established in the study reach is based on sea level (see definition on page IV). During field surveys along the Sacramento River, it was found that some bench marks had settled. In those cases, datum adjustments, as shown in table 1, were applied to stages recorded at gaging stations. All gages in the reach between Sacramento River at Sacramento and Sacramento Weir are included in a network using a bench mark (known as TIDAL 3) near the Sacramento River at Sacramento gage as the reference elevation. All high-water marks, top of levee, the crest of the Sacramento Weir, and flood-plain elevations are based on bench-mark elevations established by levels conducted in 1960,1976 , and 1987. 


\section{PEAK STAGE AND DISCHARGE}

Annual peak stage and discharge data for gages on the Sacramento River at Verona, American River at Fair Oaks, and Sacramento River at Sacramento are given in tables 2,3 , and 4 . The peak stage of $39.11 \mathrm{ft}(92,900 \mathrm{ft} / \mathrm{s})$ on the Sacramento River at Verona, February 20, 1986, (table 2) was the highest for the period of record 1914-87 (no data for years $1918-20$ and 1922-25). The previous peak gage height at Verona was $38.20 \mathrm{ft}$ on March 1, 1940. To reduce the flow of the Sacramento River in the vicinity of Sacramento, the Sacramento Weir (fig. 2, pl. 1), located $3 \mathrm{mi}$ upstream from the mouth of the American River and $15.4 \mathrm{mi}$ downstream from Verona, was opened February 15, 1986. On February 20. a peak of $128,000 \mathrm{ft}^{3} / \mathrm{s}$ was discharged across the sacramento Weir to the Yolo Bypass (table 5).

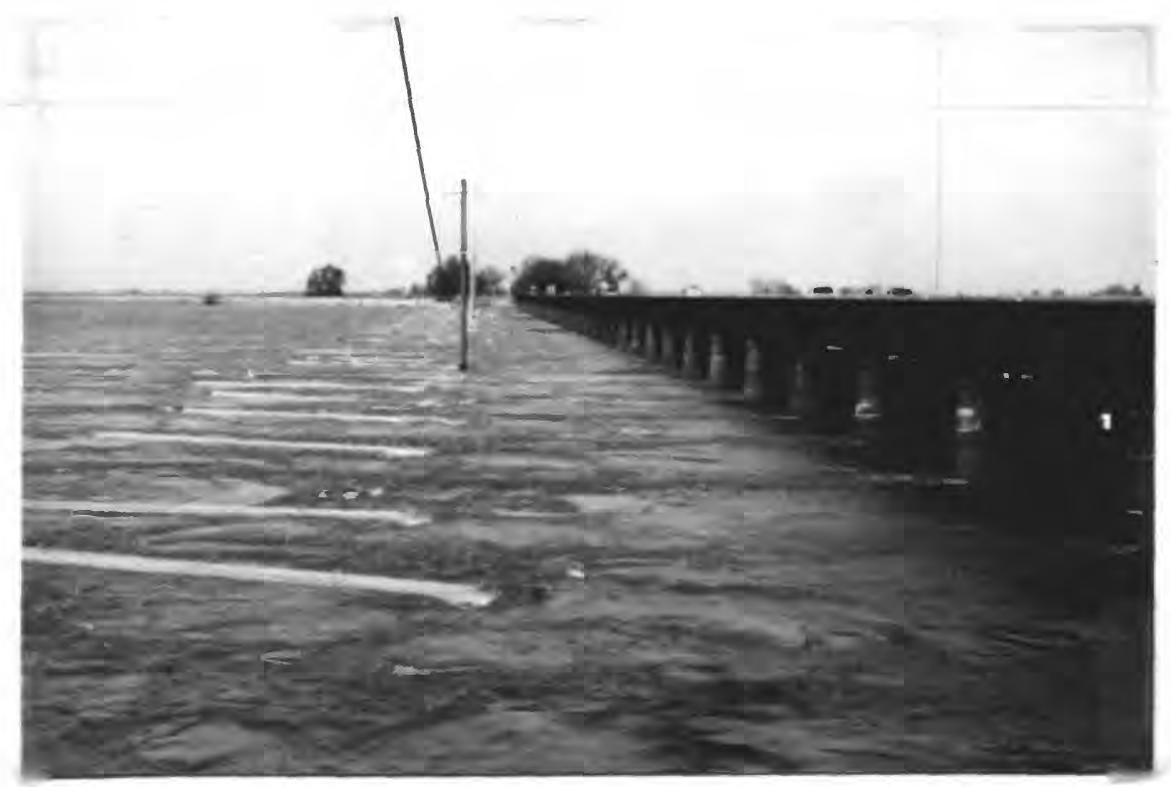

FIGURE 2. Sacramento Weir spill to Yolo Bypass near Sacramento. February 18, 1986. View from left bank at downstream side of weir. Length of weir 1,830 feet. Note weir gates floating in stream.

The peak of record on the American River at Fair Oaks (table 3) prior to completion of Folsom Dam occurred on November 21, 1950 (discharge 180,000 $\mathrm{ft}^{3} / \mathrm{s}$ ). The highest peak flow (discharge $134,000 \mathrm{ft}^{3} / \mathrm{s}$, table 5) since construction of Folsom Dam in 1953 was recorded on February 19, 1986, at the American River at Fair Oaks gage. The previous maximum flow since completion of Folsom Dam was $115,000 \mathrm{ft}^{3} / \mathrm{s}$ on December 23, 1964 (table 3). 
The peak flow of the Sacramento River at Sacramento (table 4) was 117,000 $\mathrm{ft}^{3} / \mathrm{s}$, on February 19, 1986, caused by high inflow from the American River (table 5). A similar flow occurred on February 20, although the gage height was $0.04 \mathrm{ft}$ lower than on February 19 (table 5). High flows on February 20 were the result of tributary inflow to the sacramento River upstream from Sacramento, as recorded at the Verona gage on February 20. Stages on the Sacramento River at Sacramento gage less than about $13 \mathrm{ft}$ are affected by backwater from the tide. The February 1986 peak stage of $30.58 \mathrm{ft}$ at the Sacramento River at Sacramento gage (fig. 3, table 4) was the highest of record since January 1862 (U.S. Geological Survey, 1959). The peak stage recorded between 1862 and 1949 was $29.6 \mathrm{ft}$ on January 17, 1909 (discharge 103,000 ft ${ }^{3} / \mathrm{s}$ ). Gage heights collected at this site from November 1879 to May 1888 and from December 1890 to September 1950 are contained in reports of the U.S. Weather Bureau (U.S. Geological Survey, 1959).

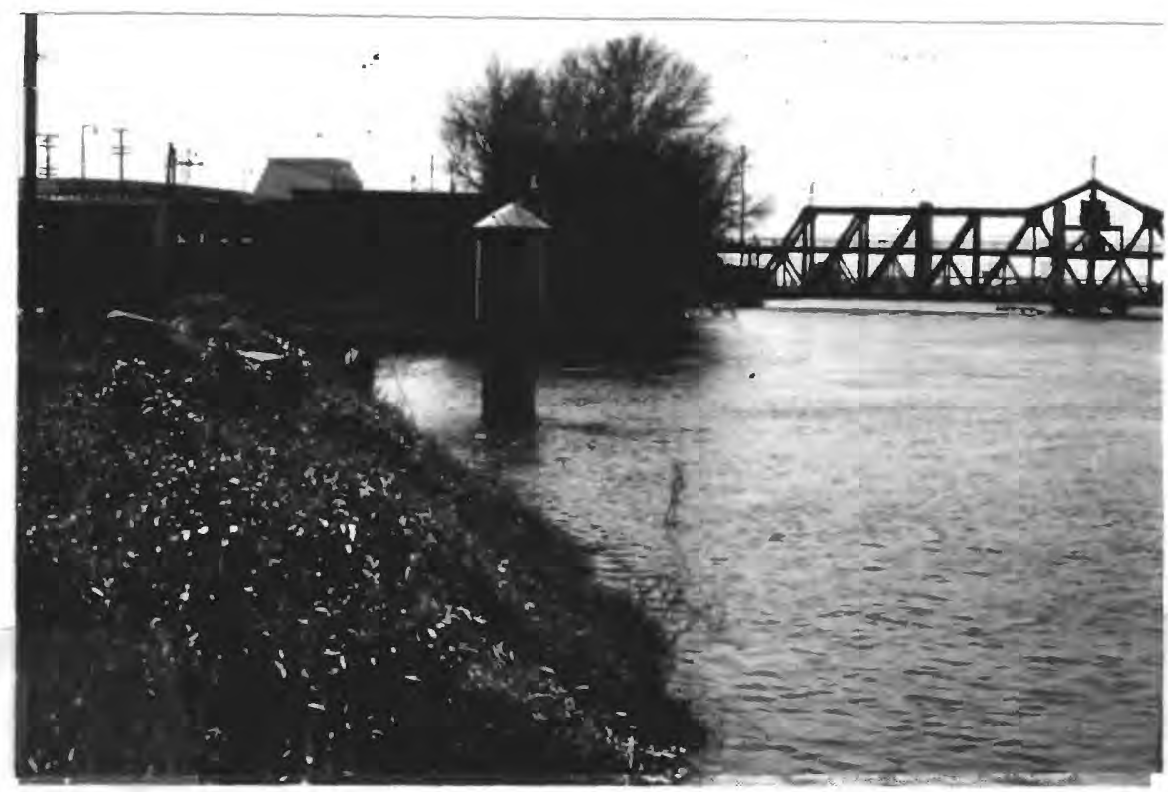

FIGURE 3. Sacramento River at Sacramento gage, February 18 , 1986. View downstream along left bank. Gage height 29.1 feet. Peak gage height during flood, 30.6 feet on February 19, 1986. 


\section{FLOOD PROFILES}

The profile of the February 1986 flood in the reach between gaging stations at Freeport and Verona is shown on plate 1. The influence of flood releases to the Yolo Bypass at the Sacramento Weir is indicated by the reverse water-surface slope and a corresponding drop in elevation of $0.13 \mathrm{ft}$ in the short reach between the mouth of the American River and the upstream (north) side of the Sacramento Weir. Peak stages on the reach between Freeport and Sacramento occurred on February 19, and preceded peak stages on the reach upstream from Sacramento, as shown in table 5. A water-surface profile surveyed on March 17, 1987 (which was about $0.2 \mathrm{ft}$ lower than the peak for the 1987 water year at the Sacramento River at Verona gage, old site), is generally parallel to the February 1986 flood profile except in the vicinity of the sacramento Weir (pl. 1). The crest of the Sacramento Weir varies in elevation from $19.9 \mathrm{ft}$ at the north end to $20.6 \mathrm{ft}$ at the south end.

Approximate profiles of the top of levee and flood plain on either bank, depending where the level lines were run, are shown on plate 1 . Those profiles indicate the approximate free board (clearance above the water surface to the top of levee) and height of water above the adjacent flood plain (bankfull stage) on the shoreward side of the levee during the flood.

\section{REFERENCES CITED}

Brice, J.C., and Blodgett, J.C., 1978, Countermeasures for hydraulic problems at bridges, volume 1--Analysis and assessment: Federal Highway Administration Report No. FHWA-RD-78-162, 169 p.

California Department of Public Works, 1928, Stream flow data for flood season of 1928, Sacramento and San Joaquin Valleys: California Division of Water Resources, October 1928,235 p. 1932a, Stream flow data for flood seasons 1913-14 to 1924-25: November 1932, 162 p. 1932b, Stream flow data for flood season of 1926-27: November 1932, $101 \mathrm{p}$. 1932c, Stream flow data for flood season of 1928-29, 1929-30, 1930-31: November 1932,201 p. 1932d, Stream flow data for flood season of 1931-32: November 1932, $99 \mathrm{p}$. 1933a, Stream flow data for flood season of 1925-26: May 1933, 102 p. 1933b, Stream flow data for flood season of 1932-33: June 1933, 75 p. 1934, Stream flow data for flood seasons of 1933-34: June 1934, 71 p. 1943, Flood flows and stages in Sacramento and lower San Joaquin Valleys, 1934-42: September 1943, 439 p.

1944, Flood flows and stages 1942-44: September 1944, 187 p.

1946, Flood flows and stages 1944-46: August 1946, 192 p. 1948, Flood flows and stages 1946-48: September 1948, 186 p.

National Oceanic and Atmospheric Administration, 1986, Climatological data California, February 1986: National Oceanic and Atmospheric Administration, v. 90, no. 2, 53 p.

U.S. Geological Survey, 1959, Compilation of records of surface waters of the United States through September 1950, part 11-B. Pacific slope basins in California, Central Valley: U.S. Geological Survey Water-Supply Paper 1315-A, 459 p. 
TABLE 1.--Gaging stations in study reach

[USGS, U.S. Geological Survey; DWR, California Department of Water Resources]

\begin{tabular}{|c|c|c|c|c|c|}
\hline Station & Number & $\begin{array}{l}\text { River } \\
\text { mile }\end{array}$ & $\begin{array}{l}\text { Datum } \\
\text { adjustment } \\
\text { (feet) }\end{array}$ & $\begin{array}{l}\text { Operating } \\
\text { agency }\end{array}$ & $\begin{array}{l}\text { Period } \\
\text { of } \\
\text { record }\end{array}$ \\
\hline $\begin{array}{l}\text { Sacramento River at } \\
\text { Verona (old site) }\end{array}$ & $\begin{array}{r}11425500 \\
2 \mathrm{AO} 2150\end{array}$ & 78.9 & -3.00 & $\begin{array}{l}\text { USGS } \\
\text { DWR }\end{array}$ & 1914-date \\
\hline $\begin{array}{l}\text { Sacramento River at } \\
\text { Verona (new site) }\end{array}$ & 11425500 & 78.1 & -3.00 & USGS & 1986-date \\
\hline $\begin{array}{l}\text { Sacramento River above } \\
\text { Sacramento Weir, near } \\
\text { Sacramento }\end{array}$ & ${ }^{2} \mathrm{AO} 2108$ & 63.5 & $3-.28$ & DWR & 1963-date \\
\hline $\begin{array}{l}\text { Sacramento Weir spill } \\
\text { to Yolo Bypass, } \\
\text { near Sacramento }\end{array}$ & $\begin{array}{r}11426000 \\
2 \mathrm{AO} 2903\end{array}$ & 63.5 & $\left({ }^{4}\right)$ & DWR & 1926-date \\
\hline $\begin{array}{l}\text { Sacramento River near } \\
\text { Bryte (at Bryte } \\
\text { Laboratory) }\end{array}$ & ${ }^{2} \mathrm{~A} 02104$ & 62.1 & $3-.54$ & DWR & 1960-date \\
\hline $\begin{array}{l}\text { American River at } \\
\text { Fair Oaks }\end{array}$ & $\begin{array}{r}11446500 \\
2 \mathrm{~A} 07175\end{array}$ & $\left({ }^{4}\right)$ & 71.53 & USGS & 1904-date \\
\hline $\begin{array}{l}\text { American River at } \\
\text { Sacramento }\end{array}$ & ${ }^{2 A 07140}$ & $(4)$ & -3.07 & DWR & $\begin{array}{l}1921,24 \\
1925 \text {-date }\end{array}$ \\
\hline $\begin{array}{l}\text { Sacramento River at } \\
\text { Sacramento }\end{array}$ & $\begin{array}{r}{ }^{5} 11447500 \\
2 \mathrm{~A} 02100\end{array}$ & 59.6 & $3-.15$ & USGS & $\begin{array}{l}61904-05 \\
1921 \\
1948-87\end{array}$ \\
\hline $\begin{array}{l}\text { Sacramento River near } \\
\text { Freeport (auxiliary } \\
\text { water-stage recorder) }\end{array}$ & 11447650 & 48.6 & 0 & USGS & $1955-81$ \\
\hline $\begin{array}{l}\text { Sacramento River at } \\
\text { Freeport (acoustic } \\
\text { velocity meter site) }\end{array}$ & $\begin{array}{l}11447650 \\
2_{B} 9-1850\end{array}$ & 46.0 & 0 & USGS & 1980-date \\
\hline
\end{tabular}

${ }^{1}$ River mile distances computed on basis of river mile location shown on U.S. Geological Survey maps (plate 1).

${ }^{2}$ California Department of Water Resources station number.

${ }^{3}$ Adjustment to sea level based on levels in 1987. Adjustment applied for water years 1986 and 1987 only.

${ }^{4}$ Not applicable.

${ }^{5}$ Gage heights collected in vicinity of "at Sacramento" gage November 1879 to May 1888, and December 1890 to September 1963 are contained in reports of the National Weather Service.

${ }^{6}$ Gage heights only for water years $1980-87$. 
TABLE 2.--Annual peak stage and discharge of the Sacramento River at Verona (old site)

[Data for years 1914-29 obtained from California Department of Public Works, 1914-25, 1932a; 1926, 1933a; 1927, 1932b; 1928, 1928; 1929, 1932c. Gage heights adjusted to sea leve1]

\begin{tabular}{|c|c|c|c|}
\hline $\begin{array}{l}\text { Water } \\
\text { year }\end{array}$ & Date & $\begin{array}{l}\text { Gage height } \\
\text { (feet) }\end{array}$ & $\begin{array}{l}\text { Peak discharge } \\
\text { (cubic feet per second) }\end{array}$ \\
\hline 1914 & Jan. 4, 1914 & 1233.6 & \\
\hline 1915 & Feb. $\quad 5,1915$ & 1232.9 & \\
\hline 1916 & Feb. 14, 1916 & 1231.5 & \\
\hline 1917 & Mar. 2, 1917 & 1231.3 & \\
\hline $1918-20$ & No data & & \\
\hline 1921 & Feb. 2,1921 & 32.6 & \\
\hline $1922-25$ & No data & & \\
\hline 1926 & Feb. 7,1926 & ${ }^{3} 32.4$ & \\
\hline 1927 & Feb. 22,1927 & 35.3 & \\
\hline 1928 & Mar. 28, 1928 & 34.75 & \\
\hline 1929 & Feb. $\quad 8,1929$ & 25.2 & \\
\hline 1930 & Dec. 17, 1929 & 31.79 & 57,400 \\
\hline 1931 & Jan. 25,1931 & 19.77 & 26,600 \\
\hline 1932 & Dec. 30,1931 & 30.77 & 53,300 \\
\hline 1933 & Mar. 31, 1933 & 22.51 & 34,000 \\
\hline 1934 & Jan. 4, 1934 & 30.34 & 47,900 \\
\hline 1935 & Apr. 10,1935 & 32.75 & 55,800 \\
\hline 1936 & Feb. 25,1936 & 33.62 & 61,800 \\
\hline 1937 & Mar. 25, 1937 & 31.66 & 52,900 \\
\hline 1938 & Dec. 14,1937 & 35.23 & 68,400 \\
\hline 1939 & Mar. 16, 1939 & 20.37 & 30,600 \\
\hline 1940 & Mar. 1,1940 & 38.20 & 79,200 \\
\hline 1941 & Feb. 13, 1941 & 35.65 & 68,900 \\
\hline 1942 & Feb. 8,1942 & 37.80 & 78,000 \\
\hline 1943 & Jan. 25,1943 & 34.75 & 67,400 \\
\hline 1944 & Mar. 6,1944 & 26.42 & 47,100 \\
\hline 1945 & Feb. 6,1945 & 32.77 & 56,200 \\
\hline 1946 & Dec. 31,1945 & 33.83 & 61,200 \\
\hline 1947 & Feb. 25, 1947 & 28.05 & 47,000 \\
\hline 1948 & Apr. 19,1948 & 31.07 & 56,600 \\
\hline 1949 & Mar. 14,1949 & 30.56 & 56,200 \\
\hline 1950 & Feb. 7,1950 & 32.18 & 59,500 \\
\hline 1951 & Nov. 22,1950 & 34.06 & 64,300 \\
\hline 1952 & Feb. 4, 1952 & 32.83 & 61,800 \\
\hline 1953 & Jan. 15, 1953 & 33.44 & 66,300 \\
\hline 1954 & Feb. 19, 1954 & 31.82 & 61,500 \\
\hline
\end{tabular}


TABLE 2.--Annual peak stage and discharge of the Sacramento River at Verona (old site)--Continued

\begin{tabular}{|c|c|c|c|}
\hline $\begin{array}{l}\text { Water } \\
\text { year }\end{array}$ & Date & $\begin{array}{l}\text { Gage height } \\
\quad(\text { feet })\end{array}$ & $\begin{array}{l}\text { Peak discharge } \\
\text { (cubic feet per second) }\end{array}$ \\
\hline 1955 & Dec. 11, 1954 & 22.89 & 36,900 \\
\hline 1956 & Dec. 23, 1955 & 36.81 & 71,400 \\
\hline 1957 & Feb. 26, 1957 & 31.61 & 65,500 \\
\hline 1958 & Feb. 26, 1958 & 35.47 & 69,200 \\
\hline 1959 & Feb. 19, 1959 & 32.26 & 62,900 \\
\hline 1960 & Feb. 9, 1960 & 32.45 & 64,500 \\
\hline 1961 & Feb. 13, 1961 & 27.05 & 48,300 \\
\hline 1962 & Feb. 16, 1962 & 32.55 & 62,300 \\
\hline 1963 & Feb. 1, 1963 & 35.14 & 69,400 \\
\hline 1964 & Jan. 23, 1964 & 28.36 & 50,500 \\
\hline 1965 & Dec. 25,1964 & 36.65 & 74,200 \\
\hline 1966 & Jan. 10, 1966 & 27.90 & 50,800 \\
\hline 1967 & Feb. 1, 1967 & 33.88 & 67,100 \\
\hline 1968 & Feb. 28, 1968 & 30.48 & 58,600 \\
\hline 1969 & Jan. 26, 1969 & 34.11 & 68,500 \\
\hline 1970 & Jan. 26, 1970 & 36.21 & 77,800 \\
\hline 1971 & Dec. 5, 1970 & 31.00 & 63,200 \\
\hline 1972 & Mar. 2, 1972 & 18.74 & 30,000 \\
\hline 1973 & Jan. 20,1973 & ${ }^{4} 31.0$ & 65,800 \\
\hline 1974 & Jan. 20, 1974 & 34.90 & 74,900 \\
\hline 1975 & Mar. 26, 1975 & 31.17 & 63,700 \\
\hline 1976 & Dec. 8,1975 & 17.80 & 27,100 \\
\hline 1977 & Jan. $\quad 5,1977$ & 11.52 & 14,200 \\
\hline 1978 & Jan. 17,1978 & 32.52 & 68,300 \\
\hline 1979 & Feb. 24, 1979 & 29.63 & 57,100 \\
\hline 1980 & Feb. 22, 1980 & 35.12 & 80,900 \\
\hline 1981 & Jan. 31,1981 & 26.89 & 53,300 \\
\hline 1982 & Dec. 21,1981 & 36.72 & 72,200 \\
\hline 1983 & Mar. 4,1983 & 35.82 & 79,400 \\
\hline 1984 & Dec. 28,1983 & 35.42 & 78,100 \\
\hline 1985 & Nov. 30,1984 & 21.08 & 35,400 \\
\hline 1986 & Feb. 20, 1986 & 39.11 & 92,900 \\
\hline 1987 & Mar. $16,1.987$ & 21.35 & 37,400 \\
\hline
\end{tabular}

${ }^{1}$ Staff readings from gage located on right bank of Feather River $60 \mathrm{ft}$ upstream from junction with Sacramento River.

2 Once daily staff readings.

3 Peak on April 9, 1926, at $31.8 \mathrm{ft}$.

${ }^{4}$ Gage height is an estimate based on daily average discharge. 
TABLE 3.--Annual peak stage and discharge of the American River at -Fair Oaks

[Datum of gage is 71.53 feet above sea level. Prior to Nov. 7, 1930, nonrecording gages or water-stage recorders at several sites 2.2 miles downstream ral1 at datum 5.74 feet lower; from Nov. 7, 1930, to Dec. 31, 1957, at site 2.2 miles downstream at datum 6.74 feet lower. Dec. 31, 1957, to July 15, 1970, at datum 6.00 feet higher]

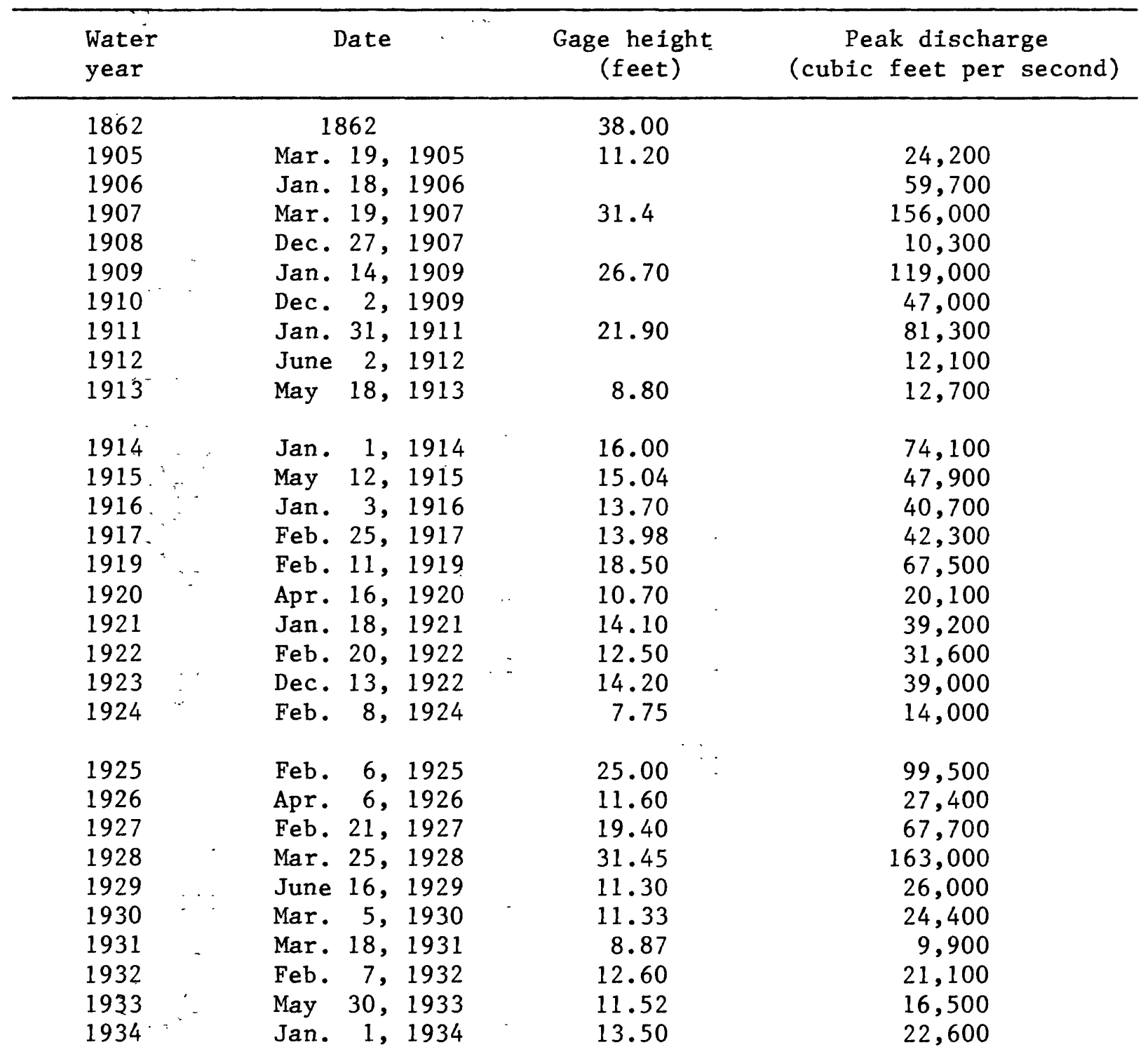



TABLE 3.--Annual peak stage and discharge of the American River at Fair Oaks--Continued

\begin{tabular}{llrr}
$\begin{array}{l}\text { Water } \\
\text { year }\end{array}$ & \multicolumn{1}{c}{ Date } & $\begin{array}{c}\text { Gage height } \\
\text { (feet) }\end{array}$ & $\begin{array}{c}\text { Peak discharge } \\
\text { (cubic feet per second) }\end{array}$ \\
\hline 1970 & Jan. 19, 1970 & 12.82 & 56,700 \\
1971 & Jan. 15, 1971 & 3.73 & 8,270 \\
1972 & Feb. 9, 1972 & 2.89 & 6,060 \\
1973 & Jan. 14, 1973 & 9.42 & 32,700 \\
1974 & Jan. 17, 1974 & 8.46 & 27,600 \\
1975 & Mar. 25, 1975 & 3.85 & 8,450 \\
1976 & Oct. 17, 1975 & 1.19 & 3,770 \\
1977 & Dec. 6, 1976 & .56 & 1,920 \\
1978 & May 5, 1978 & 3.92 & 8,660 \\
1979 & Feb. 23, 1979 & 6.14 & 16,500 \\
1980 & Jan. 15, 1980 & 17.27 & \\
1981 & June 9, 1981 & 2.42 & 84,800 \\
1982 & Feb. 16, 1982 & 17.92 & 5,140 \\
1983 & Dec. 22, 1982 & 10.14 & 91,100 \\
1984 & Dec. 28, 1983 & 12.18 & 36,200 \\
1985 & Dec. 7, 1984 & 1.57 & 48,500 \\
1986 & Feb. 19, 1986 & 27.96 & 5,200 \\
& & & 134,000 \\
\hline
\end{tabular}


TABLE 4.--Selected annual peak stage and discharge of the Sacramento River at Sacramento

[Data for years 1920-48 obtained from California Department of Public Works, $1920-25,1932 \mathrm{a}$; 1926, 1933a; 1927, 1932b; 1928, 1928; 1929-31, 1932c; 1932, 1932d; 1933, 1933b; 1934, 1934; 1935-42, 1943; 1943-44, 1944; 1945-46, 1946; 1947-48, 1948. Peak discharge data for 1920-48 not available. Gage heights for years 1963-85 may be higher than actual peak stages by about $0.1 \mathrm{ft}$ because of variable settlement of reference bench marks]

\begin{tabular}{|c|c|c|c|}
\hline $\begin{array}{l}\text { Water } \\
\text { year }\end{array}$ & Date & $\begin{array}{l}\text { Gage height } \\
\text { (feet) }\end{array}$ & $\begin{array}{l}\text { Peak discharge } \\
\text { (cubic feet per second) }\end{array}$ \\
\hline 1909 & Jan. 17, 1909 & 29.6 & 103,000 \\
\hline 1920 & Apr. 18,1920 & 20.8 & \\
\hline 1921 & Jan. 19,1921 & 26.4 & \\
\hline 1922 & Feb. 21,1922 & 24.3 & \\
\hline $1923-24$ & No data & & \\
\hline 1925 & Feb. 6,1925 & 27.9 & \\
\hline 1926 & Apr. 9,1926 & 24.7 & \\
\hline 1927 & Feb. 18,1927 & 26.9 & \\
\hline 1928 & Mar. 26,1928 & 29.5 & \\
\hline 1929 & Feb. 7,1929 & 17.0 & \\
\hline 1930 & Mar. 6,1930 & 24.3 & \\
\hline 1931 & Mar. 21, 1931 & 10.8 & \\
\hline 1932 & Dec. 29, 1931 & 23.0 & \\
\hline 1933 & Apr. 1, 1933 & 14.0 & \\
\hline 1934 & Jan. 4,1934 & 21.2 & \\
\hline 1935 & Apr. 8,1935 & 28.6 & \\
\hline 1936 & Feb. 22, 1936 & 28.7 & \\
\hline 1937 & Mar. 22, 1937 & 26.3 & \\
\hline 1938 & Feb. 11,1938 & 27.7 & \\
\hline 1939 & Mar. 17, 1939 & 111.6 & \\
\hline 1940 & Feb. 27,1940 & 28.5 & \\
\hline 1941 & Dec. 28,1940 & 27.25 & \\
\hline 1942 & Jan. 27, 1942 & 28.25 & \\
\hline 1943 & Jan. 22, 1943 & 28.85 & \\
\hline 1944 & Mar. 5,1944 & 17.60 & \\
\hline 1945 & Feb. 2, 1945 & 27.64 & \\
\hline 1946 & Dec. 29,1945 & 27.28 & \\
\hline 1947 & Feb. 15,1947 & 18.18 & \\
\hline 1948 & Apr. 18,1948 & 22.50 & \\
\hline 1949 & Mar. 14, 1949 & 20.36 & 61,300 \\
\hline 1950 & Feb. 7,1950 & 24.55 & 80,200 \\
\hline 1951 & Nov. 21,1950 & 30.14 & 104,000 \\
\hline 1952 & Jan. 15, 1952 & 26.84 & 87,400 \\
\hline 1953 & Jan. 21, 1953 & 25.46 & 80,000 \\
\hline 1954 & Mar. 11, 1954 & 23.73 & 76,800 \\
\hline
\end{tabular}


TABLE 4.--Selected annual peak stage and discharge of the Sacramento River at Sacramento--Continued

\begin{tabular}{|c|c|c|c|}
\hline $\begin{array}{l}\text { Water } \\
\text { year }\end{array}$ & Date & $\begin{array}{l}\text { Gage height } \\
\text { (feet) }\end{array}$ & $\begin{array}{c}\text { Peak discharge } \\
\text { (cubic feet per second) }\end{array}$ \\
\hline 1955 & Dec. 10,1954 & 13.89 & 44,000 \\
\hline 1956 & Dec. 23,1955 & 28.67 & 95,300 \\
\hline 1957 & Mar. 6, 1957 & 25.75 & 84,700 \\
\hline 1958 & Apr. 7,1958 & 27.62 & 88,900 \\
\hline 1959 & Feb. 20, 1959 & 21.64 & 67,400 \\
\hline 1960 & Feb. 10, 1960 & 21.39 & 69,600 \\
\hline 1961 & Feb. 14,1961 & 15.89 & 49,800 \\
\hline 1962 & Feb. 16, 1962 & 22.85 & 70,500 \\
\hline 1963 & Feb. 1, 1963 & 28.52 & 98,100 \\
\hline 1964 & Jan. 23, 1964 & 17.31 & 52,800 \\
\hline 1965 & Dec. 25,1964 & 29.36 & 99,700 \\
\hline 1966 & Jan. 10, 1966 & 16.80 & 53,000 \\
\hline 1967 & Jan. 31, 1967 & 27.40 & 90,900 \\
\hline 1968 & Feb. 29,1968 & 20.80 & 66,800 \\
\hline 1969 & Jan. 21, 1969 & 28.18 & 95,500 \\
\hline 1970 & Jan. 24, 1970 & 28.24 & 94,100 \\
\hline 1971 & Dec. 5,1970 & 21.79 & 73,700 \\
\hline 1972 & Mar. 6, 1972 & 10.29 & 33,300 \\
\hline 1973 & Jan. 19,1973 & 26.74 & 93,400 \\
\hline 1974 & Jan. 21,1974 & 27.18 & 95,000 \\
\hline 1975 & Mar. 26, 1975 & 21.85 & 74,400 \\
\hline 1976 & Dec. 8,1975 & 9.19 & 30,600 \\
\hline 1977 & Jan. 5,1977 & 25.18 & 13,700 \\
\hline 1978 & Mar. 9, 1978 & 23.70 & 79,300 \\
\hline 1979 & Feb. 24,1979 & 21.43 & 71,300 \\
\hline 1980 & Jan. 15, 1980 & ${ }^{3} 27.83$ & ${ }^{4} 94,600$ \\
\hline 1981 & Jan. 31,1981 & ${ }^{5} 15.68$ & 454,100 \\
\hline 1982 & Feb. 16, 1982 & 27.70 & ${ }^{4} 103,000$ \\
\hline 1983 & Dec. 24,1982 & ${ }^{6} 27.20$ & ${ }^{4} 97,800$ \\
\hline 1984 & Dec. 26,1983 & 27.40 & ${ }^{4} 94,500$ \\
\hline 1985 & Nov. 30,1984 & 12.17 & ${ }^{4} 42,000$ \\
\hline 1986 & Feb. 19, 1986 & ${ }^{7} 30.58$ & ${ }^{4} 117,000$ \\
\hline 1987 & Mar. 17,1987 & $\begin{array}{lll}78 & 10.78\end{array}$ & 439,400 \\
\hline
\end{tabular}

${ }^{1}$ Daily mean gage height.

${ }^{2}$ Maximum elevation Jan. 2, 1977.

${ }^{3}$ Maximum elevation Jan. 14, 1980.

${ }^{4}$ Discharge determined at Sacramento River at Freeport gaging station.

${ }^{5}$ Maximum elevation Feb. 1, 1981.

${ }^{6}$ Maximum elevation Dec. 23, 1982

${ }^{7}$ Gage height for years $1986-87$ corrected for settlement of reference bench marks based on level surveys in 1987 .

${ }^{8}$ Maximum elevation March 16, 1987. 
TABLE 5.--February 1986 peak stage and discharge at selected gaging stations on the American and Sacramento Rivers

[All gage heights referenced to sea level]

\begin{tabular}{|c|c|c|c|c|}
\hline station & Day & $\begin{array}{l}\text { Time } \\
\text { (hours } \\
\text { P.s.t.) }\end{array}$ & $\begin{array}{l}\text { Gage } \\
\text { height } \\
\text { (feet) }\end{array}$ & $\begin{array}{l}\text { Discharge } \\
\text { (cubic feet } \\
\text { per second) }\end{array}$ \\
\hline $\begin{array}{l}\text { Sacramento River at Verona } \\
\text { (old site) }\end{array}$ & 20 & 0215 & 39.11 & 92,900 \\
\hline $\begin{array}{l}\text { Sacramento Weir spill to } \\
\text { Yolo Bypass, near } \\
\text { Sacramento I }\end{array}$ & 20 & 0115 & 30.56 & 128,000 \\
\hline Sacramento River near Brytel & 20 & 0015 & 30.65 & $\left({ }^{2}\right)$ \\
\hline American River at Fair Oaks & 19 & 1315 & 99.49 & 134,000 \\
\hline American River at Sacramentol & 19 & $0215-0230$ & 40.32 & $\left({ }^{2}\right)$ \\
\hline Sacramento River at Sacramento & $\begin{array}{l}19 \\
20\end{array}$ & $\begin{array}{l}1530 \\
0400\end{array}$ & $\begin{array}{l}30.58 \\
30.54\end{array}$ & $\begin{array}{l}{ }^{3} 117,000 \\
{ }^{3} 117,000\end{array}$ \\
\hline Sacramento River at Freeport & 19 & 1900 & 25.11 & 117,000 \\
\hline
\end{tabular}

${ }^{1}$ Peak stage and discharge data furnished by California Department of Water Resources.

${ }^{2}$ Not available.

${ }^{3}$ Discharge considered same as Sacramento River at Freeport gage. 